IRSH 58 (2013), Special Issue, pp. I-I 4 doi:I0.I0I7/So0208590I3000497

(C) 2013 Internationaal Instituut voor Sociale Geschiedenis

\title{
Mutiny and Maritime Radicalism in the Age of Revolution: An Introduction*
}

\author{
NiKLAS FRYKMAN \\ Department of History, Claremont McKenna College \\ 850 Columbia Ave, Claremont, CA 9 I7II, USA \\ E-mail:nfrykman@gmail.com \\ CLARE A N DERSON \\ School of Historical Studies, University of Leicester \\ 3-5 Salisbury Road, Leicester LEI $7 Q R$, UK \\ E-mail: ca26@leicester.ac.uk
}

\begin{abstract}
LeX HeERA VAN Voss
Huygens Institute for the History of the Netherlands

Prins Willem-Alexanderhof 5, PO Box 90754, 2509 LT The Hague

The Netherlands

E-mail: Lex.HeermavanVoss@huygens.knaw.nl

\author{
MARCUS REDIKER \\ Department of History, University of Pittsburgh \\ 3508 Posvar Hall, Pittsburgh, PA I5260, USA
}

E-mail: marcusrediker@yahoo.com
\end{abstract}

\begin{abstract}
AвSTRACT: The essays collected in this volume demonstrate that during the age of revolution (1760s-1840s) most sectors of the maritime industries experienced higher levels of unrest than is usually recognized. Ranging across global contexts including the Atlantic, Indian, and Pacific Oceans as well as the Caribbean, Andaman, and South China Seas, and exploring the actions of sailors, laborers, convicts, and slaves, this collection offers a fresh, sea-centered way of seeing the
\end{abstract}

* The papers presented in this volume are the outcome of two conferences. The first was organized by the editors and Emma Christopher and held on I6-I 8 June 20I I at the International Institute of Social History in Amsterdam. The second was organized by the editors and held on 2I-22 May 20I2 at the Huygens Institute for the History of the Netherlands 
confluence between space, agency, and political economy during this crucial period. In this introduction we contend that the radicalism of the age of revolution can best be viewed as a geographically connected process, and that the maritime world was central to its multiple eruptions and global character. Mutiny therefore can be seen as part of something bigger and broader: what we have chosen to call maritime radicalism, a term as well as a concept that has had virtually no presence in the literature on the revolutionary era until now.

The practice of mutiny is as old as warfare itself, but the concept and the word are of more recent provenance. Etymologically, mutiny derives from the Latin motus (motion or movement), which spawned the French word émeute (riot) and the German word Meute (mob), which in turn gave rise to Menterei, the Dutch muiterij, the French mutinerie, and soon thereafter the English mutiny. The initial meaning of the word was diffuse, suggesting a general state of tumult, unruly discord, and social disturbance, but during the ferocious wars that tore apart the continent in the sixteenth and seventeenth centuries mutiny affixed itself more specifically to the collective rebellions that erupted with growing frequency inside Europe's hugely expanded armed forces. The Spanish army of Flanders, a massive force of 70,000 men, appears to have been especially afflicted, suffering no fewer than 37 major mutinies between I 589 and I607, many of them lasting for multiple years and involving between 3,000 and 4,000 soldiers each time. ${ }^{\text {I }}$

Mutiny thus entered Europe's military vocabulary at a time when nascent nation-states began to transform their armies from chaotic collections of drifters, forced recruits, feudal retainers, and paid mercenaries into the standardized, tightly organized, and highly hierarchical warmaking machines of the modern era. As part of this military revolution, war-workers were deskilled and turned into replaceable cogs through a program of extensive drilling based on the time and motion studies carried out by the Dutch military pioneers Maurice and William Louis of Nassau, subsequently refined and implemented with deadly success by the legendary Swedish warrior-king Gustavus Adolphus. ${ }^{2}$

in The Hague. The first conference was funded by the Royal Netherlands Academy of Arts and Sciences, the International Institute of Social History, the University of Pittsburgh, and Stichting Professor van Winterfonds. The second conference was funded by the University of Pittsburgh, the Huygens Institute for the History of the Netherlands, and Stichting Fonds voor de Geld-en Effectenhandel. We thank these institutions for their hospitality and generosity and the participants at both conferences for their comments on the papers.

I. Geoffrey Parker, "Mutiny and Discontent in the Spanish Army of Flanders 1 572-1607", Past

E Present, 58 (1973), p. 39.

2. Idem, The Military Revolution: Military Innovation and the Rise of the West, I500-I800, 2nd edn (Cambridge, I996), pp. I6-24. 
At sea, the process of military standardization lagged behind by a few decades, but as European powers expanded their professional war-fleets in the second half of the seventeenth century they imposed naval articles of war to create the same strictly hierarchical form of organization that had already transformed their armies. All traces of collective decision-making, long a prominent element of North Atlantic maritime culture, were obliterated. The result was a micro-society that resembled tyranny in its purest form: "All that you are ordered to do is duty", an old salt advised the landsman Ned Ward at the turn of the eighteenth century. "All that you refuse to do", he continued, "is mutiny". 3

The authoritarianism of the militarized work environment, which leaves no formal room for opposition short of all-out mutiny, explains in part why mutinous soldiers and sailors have repeatedly been in the most radically democratic, most militantly anti-imperialist vanguard of the great revolutionary movements that have thundered across the world in recent centuries: New Model Army mutineers at Putney in the midseventeenth century; sepoys at the start of the Indian Uprising in I 857 ; insurgent sailors at Kiel, which triggered the revolution that toppled the German Kaiser in 1918; seamen at Kronstadt who in I92 I challenged the increasingly authoritarian rule of the Bolsheviks; or, most recently, American GIs who, with their mass refusals, marches, protests, and anti-officer violence ("fragging"), undermined the war effort in Vietnam during the late i960s and early i970s. ${ }^{4}$

Until recently, the scarcity of reliable data has made it seem nearly impossible to estimate the actual incidence of mutiny during the age of sail. The events themselves are notoriously underreported, shrouded in "a double conspiracy of silence" since no one involved had an interest in their involvement becoming known - for officers it might result in a career-ending stigma, for the mutineers themselves in a life-ending sentence. ${ }^{5}$ As a consequence we must assume that extant evidence represents only a small proportion of actual events. And yet, where quantifiable data has been uncovered and analyzed, the results have been perfectly astonishing. New work has revealed previously unknown

3. Quoted in Marcus Rediker, Between the Devil and the Deep Blue Sea: Merchant Seamen, Pirates, and the Anglo-American Maritime World, 1700-1750 (Cambridge, 1987), p. 21 I.

4. James Holstun, Ehud's Dagger: Class Struggle in the English Revolution (London, 2000), pp. 192-256; C.A. Bayly, Indian Society and the Making of the British Empire (Cambridge, 1988), ch. 6; Michael Epkenhans, "Red Sailors' and the Demise of the German Empire, I91 8", in Christopher M. Bell and Bruce A. Elleman (eds), Naval Mutinies of the Twentieth Century: An International Perspective (London, 2003), pp. 80-105; Paul Avrich, Kronstadt $192 \mathrm{I}$ (Princeton, NJ, 1970); David Cortright, Soldiers in Revolt: GI Resistance During the Vietnam War (Chicago, IL, 1975).

5. James C. Scott, Two Cheers for Anarchism: Six Easy Pieces on Autonomy, Dignity, and Meaningful Work and Play (Princeton, NJ, 2012), pp. 8-9. 
mutinies and other forms of resistance in the Indian Ocean convict trade. ${ }^{6}$ Recent research in North Atlantic naval archives meanwhile suggests that at least one-third of European warships experienced some form of collective rebellion during the I790s. ${ }^{7}$ Perhaps even more impressively, the comprehensive Transatlantic Slave Trade Database demonstrates that approximately one in ten slave ships experienced a mutiny, some of them successful, most suppressed. ${ }^{8}$

The essays collected here build on such work, demonstrating unambiguously that during the age of revolution (I760s-I 840s) most sectors of the maritime industries - not just warships, but convict vessels, slave ships, and merchantmen, sailing in the Atlantic, Indian, and Pacific Oceans as well as the Caribbean, Andaman, and South China Seas - all experienced far higher levels of unrest than is usually recognized. The authors range across global contexts: exploring the actions of sailors, laborers, convicts, and slaves, and offering a fresh, sea-centered way of seeing the confluence between space, agency, and political economy during this crucial period. They make clear that we must take seriously seaborne voyages as spaces for incubation and as vectors for diffusion of political radicalism.

In this respect, the volume uses evidence of shipboard mutiny to rethink the relationship between sea and land, as well as to foreground the era's multiple geographical centers and logics of resistance from below. We contend, in other words, that the radicalism of the age of revolution can best be viewed as a geographically connected process, and that the maritime world was central to its multiple eruptions and global character. And, in understanding the global and connected character of the age of revolution, as well as its maritime and subaltern dynamics, we seek to decenter Europe and North America in our analysis and also to rethink the era's temporality, which, these essays suggest, stretches at least into the i 850 s.

\section{MARITIME RADICALISM}

Mutiny is part of something bigger and broader, what we have chosen to call maritime radicalism, a term as well as a concept that has had virtually no presence in the literature on the revolutionary era until now. But why

6. Clare Anderson, “The Ferringees are Flying - The Ship is Ours!' The Convict Middle Passage in Colonial South and Southeast Asia, I790-I 860", Indian Economic and Social History Reviere, 4I:3 (2005), pp. I43-I 86.

7. Niklas Frykman, "The Wooden World Turned Upside Down: Naval Mutinies in the Age of Atlantic Revolution" (Ph.D. thesis, University of Pittsburgh, 2010).

8. David Richardson, "Shipboard Revolts, African Authority, and the Atlantic Slave Trade", William and Mary Quarterly, 58 (200I), pp. 69-92. The Trans-Atlantic Slave Trade Database is available at www.slavevoyages.org, last accessed i 4 June 2013. 
is that so, given the near universal recognition of the ship as the most important tool of globalization before the emergence of air travel in the twentieth century? Why have events and processes that transpired onboard ship remained hidden for so long? And why has it been so hard to conceptualize maritime radicalism as a subject for historical study?

Part of the problem has been sources. Seafarers, like other poor people of the past, left relatively few records of their own: their speeches, songs, and yarns vanished on the wind, leaving few traces for historians to ponder. Because they traveled far and wide, whatever sources they may have left are often widely dispersed and not easy to locate; their "archive" is not conveniently national, and rarely if ever self-generated. Historians must therefore depend to a large extent on sources about dissident sailors and other workers generated by the authorities of the state, often as they sought to repress maritime radicalism of one kind or another. The difficulty of recovering the voices below deck through the writings of those who wielded power over their heads is greater still when insurgents and authorities spoke different languages, as was often the case with slaves, colonial subjects, labor migrants, and foreign-born sailors, such as lascars. ${ }^{9}$

There is also the problem of "terracentrism", the pervasive unconscious assumption or belief that history is made exclusively on land. Most scholars, like everyone else, see the oceans of the world as anti-spaces, as blanks that lie in between, and which are somehow unreal in comparison to the landed, national spaces that surround them. If maritime space is, to a considerable extent, "unthinkable", it therefore follows that radical action taken at sea would be rendered invisible. ${ }^{10}$

In Between the Devil and the Deep Blue Sea and The Many-HeadedHydra, Peter Linebaugh and Marcus Rediker argued that within the Anglo-Afro-Hiberno Atlantic a coherent and effective maritime radicalism was embodied in a series of fugitive connections, over vast spaces and spans of time, based on the circulation of seafaring peoples and their experiences. ${ }^{\text {I }}$ Its common characteristics included mobility and multiethnicity, both expressed in a potent phrase, the "motley crew". The guiding values and core practices of maritime radicalism were collectivism,

9. Transnationalism, the archive, and subaltern voice is explored in some detail in Clare Anderson, "Introduction to Marginal Centers: Writing Life Histories in the Indian Ocean World", Journal of Social History, 45 (201 I), pp. 335-344.

ı. Marcus Rediker, "Hydrarchy and Terracentrism", in Anna Colin and Mia Jankowicz (eds), Hydrarchy (Cairo, 20I 2), pp. I I-I 8; Marcus P.M. Vink, "Indian Ocean Studies and the 'New Thalassology", Journal of Global History, 2 (2007), pp. 4 I-62.

I I. Rediker, Between the Devil and the Deep Blue Sea; Peter Linebaugh and Marcus Rediker, The Many-Headed Hydra: Sailors, Slaves, Commoners, and the Hidden History of the Revolutionary Atlantic (Boston, MA, 2000). 
anti-authoritarianism, and egalitarianism. Radical sailors routinely stood together ("one and all" was a favorite cry), elected their officers, and divided their resources equally. All of these values and practices were eloquently expressed through the "round robin", an instrument of protest used by sailors, who drew one circle within another, wrote their demands within the interior circle, and signed their names from the edge of the inner circle to the outer one, to disguise who had begun the petition, to take strength in numbers, and to limit the captain's violent power of retaliation.

As we shall see in the essays that follow, the elements of maritime radicalism were many, ranging from the individual and solitary to the collective and massive. Sailors ran away, alone and in groups - sometimes big groups. When they remained on their vessels they engaged in a variety of acts of resistance. They challenged their captains and other officers through what was called "sea-lawyering": they grumbled or "murmured", indicating displeasure in indirect ways. They devised and signed petitions such as the round robin. They disputed orders, maintaining that law or custom underwrote their refusal to do as commanded by their officers. Negotiations subtle or overt were commonplace at sea. More dramatic forms of maritime radicalism included machine-breaking (sabotage), work stoppage, strike, running amok, as well as mutiny.

Sailors also carried maritime radicalism ashore, where they engaged in a variety of actions ranging from sabotage to arson to strikes: the sailors of London organized a massive work stoppage in 1768 , first damaging the rigging of their ships in acts of sabotage, then "striking" the sails, forcing commerce to a halt, and thus adding the word strike to the English language. ${ }^{12}$ Seafaring people were also frequent and enthusiastic leaders and participants in port city mobs (against impressment, among other causes), igniting riots and larger insurrections. Seafarers, dockworkers, and maritime artisans played important roles in revolutions - in America, France, and Saint-Domingue. The first and third of these world-shaking events contained an anti-imperial dimension, demonstrating the part seamen and their many-sided radicalism might play in peoples' war.

In this volume maritime radicalism consists of the ensemble of actions that challenged prevailing relations of power, at sea and ashore, on three interrelated levels: first, the ship itself, which was its own social and political unit; second, the nation-state or empire that formulated and enforced the laws that governed the ship; third, the system of international capitalism within which nation-states, empires, and their ships operated.

I 2. Lex Heerma van Voss, "Introduction: Industrial Disputes, Strikes", in idem and Herman Diederiks (eds), Industrial Conflict: Papers Presented to the Fourth British-Dutch Conference on Labour History, Newcastle upon Tyne (Amsterdam, I988), pp. I-9. 
The actors include naval and merchant seamen from around the Atlantic rim, Indian lascars, European and Asian convicts, and enslaved people from West Africa, the East Indies, and the Americas. The venues of maritime radicalism include vessels that ranged from the smallest canoe to the greatest three-masted ocean-going ship, as well as the docks, warehouses, waterfronts, and port cities beyond where these vessels congregated to embark and disembark people and commodities, sometimes people who were themselves considered commodities.

Events analyzed include maritime insurrections like those aboard the Amistad in I 839 and the Creole in I84I, as well as the maritime dimensions of larger upheavals, for example the American Revolution. Like mutineers, other agents of maritime radicalism could have three distinct though sometimes interrelated objectives. They could seek escape from, reform of, or revolution against ship, state, or capitalist economy. No single cultural tradition of maritime radicalism is posited; rather, we seek to understand how life and work at sea generated and transmitted radical action from below, and how seagoing passages served at times to preserve, revitalize, connect, and transform previous actions across time and vast spaces.

\section{A GLOBALIZING WORLD}

In the second half of the eighteenth and the first half of the nineteenth century, a number of colonial empires stretched out across the globe. European powers including Spain, Portugal, France, Britain, the Dutch Republic, Denmark, and Sweden traded in tobacco and sugar from the Caribbean, spices, cotton, and tea from south and east Asia, silver from Latin America, gold and slaves from Africa. To do so they conquered colonies large and small in all these areas, everywhere trying to force the local population or imported slaves and servants to produce the commodities in demand on the international markets. They built fortifications to protect their trading posts, ports, and shipping lanes, both from each other and from unconquered local forces.

Wars between European empires were frequently fought in the colonies, and their possession and the domination of the sea routes connecting them became an increasingly important reason to wage war in the first place. The War of Austrian Succession (1740-1748), the Seven Years' War (1756-1763), the American Revolutionary War (1775-1783), as well as the French Revolutionary Wars (I792-I802) and the Napoleonic Wars (I803-I8I 5 ) were all fought on a world scale.

From the American Revolutionary War onward a strong ideological element was infused into these international conflicts, reaching an apogee in the French Revolutionary Wars, when the French often encountered ideologically inspired supporters in the countries in which they fought. 
National and imperial boundary lines blurred. To give but one example from the essays that follow, after the Dutch Republic became the Batavian Republic in I795 the French and their revolutionary Dutch Batavian allies went to war against the British and their own counter-revolutionary Dutch Orangist allies over the long-contested South African Cape Colony, pivotal gateway to the Indian Ocean, China, the Spice Islands, Australia, and the South Pacific beyond.

Colonial empires offered convenient places to stow away criminals and political opponents, and convicts were also used to expand imperial frontier zones. The Dutch East India Company locked up its political enemies far away from Indonesia on Robben Island, just off Cape Town. ${ }^{13}$ The French deported to Guyana, its "dry guillotine", from I795 onward. ${ }^{14}$ The British sent convicts from Britain, Ireland, and the colonies to Australia, and from India to south-east Asia and the Andaman Islands. ${ }^{I 5}$ As metropolitan labor markets strained under the weight of escalating demand for naval and merchant seamen, plantation workers, and infantrymen for the military defense of colonial outposts, imperial rulers used the law to generate a highly mobile, super-exploitable convict labor force to build and maintain the material infrastructure of expansion. ${ }^{16}$

Another solution was to impress, conscript, and crimp workers for military service, afloat and ashore ${ }^{17} \mathrm{~A}$ third was using a rising proportion of foreign-born workers both from around the Atlantic and beyond, as did the Dutch and British East India fleets. ${ }^{18}$ A fourth was employing slaves as sailors and soldiers on board ships. The scramble for cheap labor in fact was so intense that even slaves on board slave ships were put to work, commonly performing household tasks such as preparing food, and at times sailing the ship or fighting off enemies. ${ }^{19}$ After Britain

13. Kerry Ward, Networks of Empire: Forced Migration in the Dutch East India Company (Cambridge [etc.], 2009).

I4. Miranda Spieler, Empire and Underworld: Captivity in French Guiana (Cambridge, MA, 20I 2). I 5. Clare Anderson, Subaltern Lives: Biographies of Colonialism in the Indian Ocean World, I790-I920 (Cambridge [etc.], 20I2); Ian Duffield and James Bradley (eds), Representing Convicts: New Perspectives on Convict Forced Labour Migration (Leicester, I997).

I6. Clare Anderson and Hamish Maxwell-Stewart, "Convict Labour and the Western Empires, I4I 5-I954", forthcoming in Robert Aldrich and Kirsten McKenzie (eds), Routledge History of Western Empires (London, 2013), pp. 2 I I-242.

I7. Ulbe Bosma, "European Colonial Soldiers in the Nineteenth Century: Their Role in White Global Migration and Patterns of Colonial Settlement”, Journal of Global History, 4 (2009), pp. 317-336; Denver Brunsman, The Evil Necessity: British Naval Impressment in the Eighteenth-Century Atlantic World (Charlottesville, VA [etc.], 2013).

I8. Jan Lucassen, "A Multinational and its Labor Force: The Dutch East India Company, I 595-I795", International Labor and Working-Class History, 66 (2004), pp. I 2-39; Matthias van Rossum, "De intra-Aziatische vaart: schepen, 'de Aziatische zeeman' en ondergang van de VOC?”, Tijdschrift voor Sociale en Economische Geschiedenis, 8:3 (201 I), pp. 32-69.

19. Marcus Rediker, The Slave Ship: A Human History (London, 2008), pp. 268-270. 
abolished the slave trade in 1807 , it sometimes replaced "white" soldiers with liberated Africans from intercepted slave ships ("prize negroes"), whom naval authorities disembarked in colonies in the Caribbean or on Mauritius, where they were enlisted into the army or indentured for up to fourteen years. ${ }^{20}$

Sailing a large ship was expensive, and mercantile and naval authorities tried to economize on the number of hands and on the wages they paid them, as well as on the space, food, and drink available to both crew and human cargo. Discipline in turn was harsh, and the experience of the lash was broadly shared below deck. While on board, the material circumstances of slaves, convicts, and sailors often differed only by degree, and indeed mutinous convicts - though rarely slaves, as far as we know - sometimes received critical help from one or more crew members. Such shared experiences must at times have extended to soldiers in port and on shore, who also suffered from harsh discipline, low pay, and bad food, and, much like their comrades afloat, often had to resort to desertion or mutiny so as to escape military service.

Knowledge of the ocean-world's political geography - its shifting zones of slavery and freedom, imperial domination, and peripheral autonomy was critical to mutineers, whether slaves, sailors, or convicts. Conquering the quarterdeck and becoming master of the ship was, after all, only the first step in a successful mutiny; after that, the ship had to be taken to a spot where the mutineers could sell it or at least get ashore safely. This meant that the mutineers either had to be able to navigate the ship themselves, or had to find someone from among the original crew willing and able to do so. During the late seventeenth and early eighteenth centuries, European mutineers had been able to continue sailing their ship as pirates, but by the mid-I720s, as the hold of the maritime empires over the seaways of the Atlantic tightened, this possibility disappeared from the northern hemisphere. ${ }^{2 I}$ Elsewhere, of course, piracy was still an option, for instance in the South Pacific, which was only beginning to be integrated into Britain's carceral archipelago.

But in the late eighteenth-century Atlantic and Caribbean the option of fleeing towards autonomous zones was curtailed, and successful mutineers were forced instead to depend on a keen sense of where the authority or jurisdiction of one empire fizzled out and where that of a

20. Anita Rupprecht, "When He Gets among His Countrymen, They Tell Him that He Is Free': Slave Trade Abolition, Indentured Africans and a Royal Commission”, Slavery and Abolition, 33:3 (2012), pp. I-2I; Robert J. Steinfeld, The Invention of Free Labor: The Employment Relation in English and American Law and Culture, I350-1870 (Chapel Hill, NC, I991).

21. Marcus Rediker, Villains of All Nations: Atlantic Pirates in the Golden Age (Boston, MA, 2005). 
second one began, or, in the case of slave mutineers, where slavery still flourished and where it had been abolished already. All evidence suggests that such knowledge was available, for example, about abolitionist networks or the political and juridical circumstances which made it advisable to drop weapons and ships' papers overboard, and instead trust local authorities. We know little about the nature of the networks through which such information circulated, but it seems that they were kept up-to-date in rapid response to the constantly shifting political realities of a world consumed by war and revolution, in a world characterized by increased subaltern mobility and a rapidly expanding print culture. ${ }^{22}$

Both authorities and mutineers depended on news about political shifts to determine how forces had changed or which rules applied. As global contacts grew, so did faster communication, even before technical innovations added speed. ${ }^{23}$ Official news, however, did not always spread with the same speed as proletarian communication networks. And this was not necessarily to the disadvantage of mutineers. For example, the sailors in the British squadron at the Cape knew about the Nore mutiny before their superiors did. These surreptitious lines of communication meant that revolutionary movements spread globally, even when authorities were at pains to prevent it: in the case of the Nore mutiny, from British home waters outward to the Mediterranean squadron, the Cape, the fleet in the Indian Ocean, and the Hermione frigate in the Caribbean. ${ }^{24}$

\section{REVOLUTION AT SEA}

Between the I760s and late I840s, revolutionary ferment broke out around the Atlantic world: erupting in multiple places, spreading inward and outward, and moving multi-directionally across Europe, the Americas, and the Caribbean. This resulted in a fundamental restructuring of states and empires. With American independence, Britain lost its North American colonies and turned subsequently to Asia. The French Revolution led to the abolition of the monarchy and the constitution of a new republic. And following the first and only successful revolution of enslaved peoples in world history came the birth of the independent nation of Haiti in 1804 .

22. Julius S. Scott, "The Common Wind: Currents of Afro-American Communication in the Era of the Haitian Revolution" (Ph.D., Duke University, 1986).

23. Yrjö Kaukiainen, "Shrinking the World: Improvements in the Speed of Information Transmission, c. I 820-I 870", European Review of Economic History, 5 (2001), pp. I-28.

24. Niklas Frykman, "The Mutiny on the Hermione: Warfare, Revolution, and Treason in the Royal Navy", Journal of Social History, 44 (2010), pp. I59-187. See also Julius S. Scott, "Crisscrossing Empires: Ships, Sailors, and Resistance in the Lesser Antilles in the Eighteenth Century", in Robert L. Paquette and Stanley L. Engerman (eds), The Lesser Antilles in the Age of European Expansion (Gainesville, FL, I996), pp. I28-143. 
These profound political implications, and their relationship to the global economic restructurings of the Industrial Revolution in a range of national and imperial contexts, have led to this period being characterized as the age of revolution. ${ }^{25}$ Since then, historians working from a range of perspectives have explored the intellectual history of the period; they have underscored the importance of proletarian radicalism in the production of these large-scale historical transformations; and they have unpicked some of their global relationships and connections, between and beyond the obvious sites of revolution in Europe, North America, and the Caribbean. ${ }^{26}$ But few have taken pause to consider the human conduits of such connections, or the importance of oceans as both medium and site of revolution itself.

This volume seeks entry into these historiographical debates by doing just that, and by centering subaltern insurgency in an analysis that pays close attention to the mobility, circulation, and connection of radical ideas and action - often across vast distances. It aims to produce an analysis of the proletarian worlds of the seas and oceans which foregrounds their importance as cradles and conduits of radical thought and action, and their many connections to land-based radicalism and revolution.

The authors, in line with contemporary understandings, employ a broad definition of mutiny that includes all forms of collective resistance to the constituted authority aboard ship, from muttering and murmuring all the way to bloody massacre. In most cases, mutinies erupted as a result of conflicts over specific issues inherent in the experience of life and labor on board ship, in particular its disciplinary structure. In some cases, however, it grew as well from broader, transnational ideas concerning justice and rights that were central to the age of revolution. They included, as Christopher Magra shows in his essay on the mass resistance against British naval impressment in the years leading up to the American Revolution, the idea that humans are born free and have a right to remain so, that sovereignty resides in the people, and that violence in the defense of liberty against tyranny is entirely justified.

Such ideas were not new, of course; Magra traces their genesis back to the tumultuous democratic agitation of the English Revolution. The maritime radicalism of the American Revolution was in turn echoed by European naval mutineers a generation later. Niklas Frykman demonstrates that the lower-deck rebels of the I 790 s found powerful inspiration in the most advanced democratic ideas of the revolutionary Atlantic, and

25. R.R. Palmer, The Age of the Democratic Revolution: A Political History of Europe and America, $1760-1800,2$ vols (Princeton, NJ, 1959, 1964); Eric Hobsbawm, The Age of Revolution, $1789-1848$ (London, 1975).

26. For a survey of recent work, see David Armitage and Sanjay Subrahmanyam (eds), The Age of Revolutions in Global Context, C.I760-I840 (Basingstoke, 2009). 
combined these with their own militant traditions to fuel a wholly unprecedented cycle of massive naval revolt.

Radical ideas and the autonomous political practices associated with them also flowed from beyond the European imperial orbit on to the lower deck. As Marcus Rediker forcefully argues, the Mende, Temne, and Kono mutineers on board the Amistad reconstituted a chapter of the West African Poro Society deep below deck in the hold of the slave ship, using its transplanted authority to forge iron bonds of solidarity and declare war on their captors. Similarly, Matthias van Rossum shows how, throughout the I780s, Balinese slaves aboard Dutch East Indiamen brought with them a shared knowledge of amok, a furious, collective act of violent revolt which they deployed to devastating effect on board the Mercuur in 1782 .

Shipboard unrest was not simply an extension or transfer of land-based struggles on to the sea, but rather the result of an amalgamation of geographically diffuse cultural traditions and political experiences in a highly concentrated, physically isolated, and immensely tension-filled environment, the like of which existed nowhere on land. In her essay on British convict transportation across the Indian Ocean, Bay of Bengal, and South China Sea, Clare Anderson illustrates the explosive and creative potential of a specifically maritime cosmopolitanism by showing how Indian peasant rebels, anti-imperial insurgents from across south Asia, and veteran Chinese pirates repeatedly pooled their martial knowledge to launch more than a dozen shipboard revolts in the declining years of the British East India Company's rule.

Cultural heterogeneity onboard ship could itself become a source of conflict, which in turn might precipitate mutiny, especially when class and ethnic or racial lines of division coincided, as they frequently did on slave ships, on European convict vessels sailing in Asian waters, or indeed the European owned and officered merchant ships crewed by Asian sailors that are at the center of Aaron Jaffer's fine-grained analysis of lascar resistance.

The extraordinarily large number of mutinies uncovered in these essays should not lead to the conclusion that overthrowing constituted authority on board ship was an easy thing to do, even in the age of revolution. Hamish Maxwell-Stewart demonstrates convincingly that convict vessels sailing from the British Isles to the Australian penal settlements were teeming with discontent, some of it of an explicitly radical political nature, and yet only I out of 830 voyages between 1787 and 1868 ended in a successful mutiny. But as Ian Duffield's essay suggests, would-be mutineers bided their time, waited patiently for their disembarkation in Australia, and then seized a convenient country vessel and put to sea as convict pirates in the South Pacific. The very ships designed to terrorize, remove, and reform European troublemakers 
inadvertently served to diffuse an insurrectionary spirit literally halfway around the world.

Nicole Ulrich shows that British warships did the same when they carried news of the $\mathrm{I} 797$ fleet mutinies from home waters to southern Africa, where it promptly ignited a squadron-wide mutiny at the anchorage off Cape Town, which in turn sent a spark flying from ship to shore that connected naval mutineers to unruly KhoiSan laborers and slaves in the backcountry.

Authorities elsewhere took steps to guard against the danger of similar revolutionary contagion emanating from the open sea: the very same year that major naval mutinies raged in British home waters and off the Cape, Dutch authorities in cosmopolitan Curaçao built a new fort to protect the island's capital Willemstad, and carefully positioned its guns to threaten its own naval squadron in the bay below, which, as Karwan Fatah-Black recounts, had by now a well-earned reputation for troublemaking and political militancy.

On Curaçao, the revolutionary threat of maritime radicalism come ashore never fully materialized - divisions of race, class, nationality, and politics ran too deep - but a generation later it finally came into its own when mutineers on board the slave ship Creole sailed into Bermuda's Nassau harbour, where, as Anita Rupprecht movingly describes, they found a powerful, armed community of amphibious radicals, many of them former slaves themselves, who swarmed the ship and forced the colonial government to recognize the insurgents' freedom.

\section{CONCLUSION}

Maritime historians have long tended to naturalize early modern shipboard hierarchies, whether military or civilian - to see them as imposed by the physical environment of a large deep-sea-going sailing vessel itself, and as a consequence to treat mutinies as rare anomalies, unusual breakdowns, or failures of command that are blamed on the shortcomings of particular officers, the influence of individual troublemakers, or on the unusual hardships caused by shortages of provisions or space on a particular voyage. In a revealing contrast to the dominant analyses of the revolutions that brought down the ancien régime, explanations in fact have tended to focus on almost everything except the violent, tyrannical nature of shipboard society and the lower deck's well-founded, well-reasoned decision to countenance it no longer.

Taken together, the essays collected here offer a different narrative, one that demonstrates repeatedly and unambiguously the political maturity and radical autonomy of the lower deck, whether on board slave ships, convict ships, warships, or massive East Indiamen. In so doing they also suggest a new, sea-centered geography of the revolutionary era, a dense 
and expansive network, reaching across the globe, as well as forward and backward in time, a network of seafarers that brought together, amalgamated, and mutually stimulated struggles in vastly different and distant regions.

It is notable that this network almost perfectly coincides with the rapidly unfurling tentacles of European imperialism into the Indian Ocean region, to south-east Asia, and to Australia and the south Pacific in the late eighteenth and early nineteenth centuries. The adoption of a maritime perspective thus suggests strongly the insufficiency of conceiving of this period as simply one of Atlantic revolution. But how to conceptualize the era instead - how to make sense of its powerful dialectic of revolutionary overthrow and imperial expansion, how to delineate its full geographic reach, not just across oceans but deep into continental interiors as well, and how to map these connections in turn goes well beyond the present volume to a new, even broader collective research agenda.

We opened this introductory essay with a brief genealogy of mutiny, for it is unrest at sea which constitutes the central theme of each essay in this volume. As the authors collectively make clear, the different levels of maritime radicalism were deeply connected, especially in the age of revolution - when a ship's captain, an imperial planner, and an international capitalist could all seem jointly tyrannical. Convict pirate, naval mutineer, and slave ship rebel, in turn, proposed dreams of freedom that were as expansive and widely open, as egalitarian and anti-national as the sea itself. During this age of revolution, in other words, the ship as both engine of capitalism and space of resistance was a mobile nodal point of great strategic importance, for both rulers and workers worldwide. 